Fecha de recepción: diciembre 2017 Fecha de aceptación: octubre 2018 Versión final: julio 2019

\section{Introducing Young Children to Expository Texts through Nonverbal Graphic Representations}

Ainat Guberman *

\begin{abstract}
Expository texts represent reality in a logical-scientific way. They often consist of written language and nonverbal graphic representations, such as tables and graphs, each conveying some of the text meanings (Kress \& van Leeuwen, 2006). Expository texts are prevalent in the academic world and the educational system, and are challenging at all levels of education (Berman \& Nir, 2009).

The current study explores preschool children's production of expository texts: when they need them, what resources they choose, and how these contribute to text meaning.

Method: Participants were four Israeli preschool teachers and their students, aged 3-6 years. In each preschool, the teacher documented text production events, describing the context of text production, transcribing children's conversations and adding comments explaining the photographed texts. Text analysis included identifying genre markers (Coutinho \& Miranda, 2009), text functions (Donald, 1991), verbal and nonverbal representations and text layout (Kress \& van Leeuwen, 2006).

Findings: The children produced texts of six genres: a definition, an observation table, a bird guide, an information sheet, an instruction manual, and a bi-lingual dictionary. These helped them store and retrieve information, monitor their own behavior and communicate with others. Diverse types of representations were used: written words for naming, drawing for shapes, numerals for quantity and length, and tables for organizing data. The study shows that nonverbal graphic representations enrich children's text producing resources, and may help them gradually grasp and appropriate expository text genres.
\end{abstract}

Keywords: Early childhood education - expository writing - learning modalities - active learning.

[Abstracts in Spanish and Portuguese on pages 113-114]

${ }^{*}$ Ainat Guberman has obtained a PhD in Psychology (cum laude) from the Hebrew University in Israel. Her research deals with cognitive development in early childhood and teacher education. The book "Graphic texts: literacy enhancing tools in early childhood" co-authored with Eva Teubal was published in four languages. She teaches at David Yellin College, and at the Hebrew University. 


\section{Introduction}

The current paper deals with expository texts in early childhood. Drawing heavily on Kress's social semiotic theory (Kress \& van Leeuwen, 2006; Kress, 2015; Bezemer \& Kress, $2016)^{1}$, the paper shows that, by incorporating nonverbal graphic representations into educational activities, children may begin to grasp the functions of expository text genres and appropriate them.

\section{Literacy}

In order to integrate into a literate society, children must appropriate its achievements. In 2003, UNESCO (United Nations Educational, Scientific and Cultural Organization) defined literacy as "the interest, attitude and capacity of individuals to appropriately access, manage, integrate, evaluate and reflect on written information” (p. 5). In 2005, the organization noted that literacy is such a central aspect of education that it is impossible to distinguish between the right to education and the right to literacy, and between the benefits of both (UNESCO, 2005). Since then, the definition of literacy has been broadened.

Literacy is no longer confined to written texts. According to Kress (2015), text is a semiotically coherent entity that is designed by its producer(s) to communicate meaning to intended audiences in specific cultural and social contexts. Any single meaning-conveying resource, including language, is incapable of delivering the text producer's intended meaning in its entirety. Therefore, texts are made up of different meaning-making resources, chosen from a variety of resources available to text producers, to carry part of the 'information load' of the whole text. Resources are chosen for their affordances, i.e. the characteristics that make them particularly suitable for conveying certain types of meanings. For example, gestures and facial expressions are resources suitable for conveying emotions, and images are suitable for conveying shapes. The resultant text is a 'multimodal ensemble' whose meaning is derived from the meanings of its constituents and their interactions. Even written texts are multimodal ensembles, because font type and size, bolding and layout convey meanings that language alone cannot express (Kress \& Jewitt, 2003). The multimodality of texts is more conspicuous today than ever before, because of the pervasiveness of technological resources to combine images, audio and video recordings with writing (Kress, 2015). Nonetheless, written language is still an important form of representation that is needed in order to gain access to highly valued domains of knowledge (Kress \& Sandler, 2012).

\section{Challenges involved in written text comprehension and production}

Written texts comprehension and production are complex tasks requiring proficiency in diverse skills, as well as the ability to coordinate them. One area that has attracted a lot of attention from educators and researchers is familiarity with the code that represents spoken language in writing. However, learning the code, complex as it may be, is only 
part of the knowledge children need to acquire to become literate (Scarborough, 2001; Snow, Burns \& Griffin, 1998). In the following, some of the additional aspects are briefly introduced.

\section{Linguistic skills}

To handle written texts, children must acquire a deep knowledge of vocabulary and grammar. Written texts tend to be more dense than spoken texts: They tend to include more content words -words that describe objects, actions or attributes-, and less fillers -words that do not provide specific information, like 'well' and 'so' (Clark \& Fox Tree, 2002). Written texts are associated with a different variety of language ('register') than that used in oral conversations and with less common grammatical structures (Halliday \& Hasan, 1976). Children's vocabulary size is strongly correlated with school success, concurrently as well as over time. Large and stable gaps in vocabulary size, particularly with respect to written texts' register, were found among children of different socio-economic backgrounds (Hoff, 2006). These findings were the motivating factor for intervention programs intended to enrich the vocabularies of preschoolers from poor families with limited formal education. However, evaluation studies found that intervention programs achieve very little over-all improvement (Snow, 2017).

\section{World knowledge}

Small vocabulary size may result from limited world knowledge (Snow, 2017). This conclusion is supported by the fact that monolingual children with a poor literacy background tend to do worse at school than bilingual children with a solid literacy background in their heritage language. This achievement gap exists despite the fact that monolingual children tend to have larger vocabularies in the language of instruction than bilingual children have.

\section{De-contextualization}

One of the main challenges in interpreting and producing written texts is dealing with their relative independence from the contexts in which they were formed. In daily conversations, speakers are helped by situational clues, facial expressions, intonation and gestures to interpret each other's meanings. In contrast, written texts are expected to be interpretable without recourse to such sources of information (Sweet \& Snow, 2003). Comprehension of decontextualized texts is a challenge, especially for young and inexperienced readers, since texts, such as historic or fiction texts, may contain information that is different, and even contrary to what they know. Creating decontextualized texts is even a greater challenge, since text producers have to create clear and cohesive linguistic structures. They must distinguish between common knowledge and knowledge shared only by the participants involved in the circumstances of text production (Donaldson, 1978). To do so, they must adopt the perspectives of their readers, even those who are remote and different. This task requires a high degree of meta-cognitive and meta-textual awareness 
(Rijlaarsdam et al., 2008). Authors must 'distance' themselves, observe their texts critically and edit them repeatedly until the desired outcome is achieved. Referring to adults, Bazerman (2009) believes that meta-cognitive and meta-textual awareness are not only pre-requisites for decontextualized texts production, but that they also develop as a result of extensive practice. The more children are involved in text production, the more they are able to become full members of communities that use them (Lave \& Wenger, 1991). Each text production episode can enrich text producers' resources and contribute to their consolidation as a set, enacted in text production contexts (Hammer, Elby, Scherr \& Redish, 2005).

\section{Genres}

Genres were originally defined as typical forms of language addressors use to express their intentions in similar contexts to meet addressees' expectations (Bakhtin, 1986). Typical forms include content, style and structure. Greetings and conversations are examples of activities associated with genres, each related to specific social, cultural, material, and historical contexts. Greetings among friends differ from greetings in formal meetings, and oral greetings differ from those used in letters or in mobile phone messages. Yet, each greeting has a typical form that helps their addressees comprehend them, and their addressors achieve their goals. Although Bakhtin conceived of genres as a linguistic phenomenon, genres may exist in any mode or combination of modes. Genres are enacted each time they are used, and adapted to communicators' needs in each specific interaction. Over time, genres consolidate through repeated use, and evolve as times change (Bakhtin, 1986). Genre enactment may involve more than a single genre per communicative unit (i.e., text). Text producers can choose to include characteristics ('markers') of various genres, either to adopt or to subvert them. Thus, each text is a unique entity, produced as a communicative message in a specific context and containing genre characteristics that assist in interpreting it (Coutinho \& Miranda, 2009; Heidmann \& Adam, 2007).

Bakhtin (1986) distinguished between primary and secondary genres. Primary genres are those developed in contexts of recurrent, unmediated communication among people. Secondary genres develop in complex contexts of culturally mediated communication such as literature and science. Secondary genres absorb primary genres and adapt them to their own communicative goals. For example, a dialogue in a novel loses its function as a conversation between two participants and assumes artistic functions. Similarly, arguments in a position paper are no longer the contents of a dispute, but part of a single unit of communication aiming to convince its readers to accept the author's views. The current paper deals with a specific group of secondary genres - expository texts.

\section{Expository texts}

Expository texts are prevalent in the academic world. Typical expository texts include definitions, descriptions of objects and processes, explanations of phenomena, and pres- 
entations of reasoned arguments. Children encounter expository texts mainly within the educational system, where they are used for diverse activities associated with the disciplines being studied. Some of the characteristics of expository texts, presented below, are particularly challenging.

When dealing with expository texts, readers and producers need to adopt the 'paradigmatic' way of thinking (Bruner, 1986). This is a logical-scientific way of conceptualizing and representing reality. It generates general and abstract concepts and principles that are connected by formal and logical relations. Paradigmatic thinking is intellectually challenging and markedly different from the 'narrative' way of thinking. The latter describes and explains human feelings and interactions through story-like constructions.

Expository texts appear to be objective. To achieve this effect, actors' identities, interests and actions are hidden. The resultant phenomena appear as if they were a natural, neutral, stable and uncontested state of affairs with no responsible agent, hence their objective character. Common syntactic structures used to dissolve agents are passive forms and complex noun phrases that replace verbs ('nominalizations'). For example, the phrase "people who want to buy gold" becomes "the demand for gold" (Halliday \& Martin, 1993). Another consequence of replacing verbs with complex nouns is the static character of expository texts. Actions and events become abstract objects, permitting prolonged scrutiny and analysis. Such presentation is in accordance with the paradigmatic thinking that strives for stable generalizations, but differing from every-day conceptualizations (Schleppegrell, 2001; Snow \& Uccelli, 2009).

Authors of expository texts present themselves to readers as impartial scholars. The 'uncontestable' nature of expository texts supports that impression. Additional means are: refraining from expressing personal or emotional involvement; clear marking of the epistemological status of the contents (i.e., facts vs. hypotheses, conclusions etc.) and providing substantiations for claims (Livnat, 2012). Authors demonstrate their expertise by using low frequency, precise technical terms. Such terms may require prior knowledge to be understood, and can be misleading when they also have familiar, everyday meanings (Mitchelmore, 1998).

Expository texts are even more concise and dense than other written texts: They express large amounts of information in relatively few sentences. Texts' density and grammatical complexity may also hinder comprehension (Schleppegrell, 2001; Snow \& Uccelli, 2009). De-contextualization allows for academic discourse despite distances in place and time. To achieve relative independence from a shared context, expository texts are well planned and highly organized, bearing clear markings of their constituent parts, and using explicit and precise referents and connectives. Production of cohesive and clear expository texts requires careful planning and the ability to predict diverse readers' needs for information and possibilities of (mis)interpretation (Berman \& Nir, 2009; Snow \& Uccelli, 2009).

The quality of expository texts is inferior to that of narrative texts produced by the same students, on the same subject, at different ages, including students in institutes for higher education (Berman \& Nir, 2009). Although expository texts, as characterized above, are not as prevalent today in academic contexts as previously, they still pose a challenge that students at all levels need to handle (Berman \& Nir, 2009; Snow \& Uccelli, 2009). 


\section{Nonverbal graphic representations and expository texts}

Nonverbal graphic representations include drawings, photographs, icons etc. Like written language, nonverbal graphic representations are relatively permanent external representations, i.e. they can be publicly accessible over long periods of time. Written language and nonverbal graphic representations reinforce human capabilities in three ways (Clark, 1997; Donald, 1991²; Olson, 1994): (i) Mind extension. They expand human memory and processing. For example, a drawing can support the crystallization of emerging ideas (Tversky, 1999). (ii) Mind regulation. They can help people manage their own thoughts, emotions and behaviors. Reviewing photographs is an example of using nonverbal representations to deal with a close person's death (Barthes, 1981). (ii) Mind sharing. Written language and nonverbal graphic representations are prevalent means of communication. Typical nonverbal graphic representations appearing in expository texts are maps, tables, graphs, scientific illustrations, photographs etc. Each of these has its own genres (cf. geological, political and synoptic maps), and specific affordances that make it particularly suitable to convey certain meanings: schematic illustrations are particularly useful in delineating structural composition, whereas bar graphs are a convenient means of representing quantitative comparisons. Some of these nonverbal representations appear to be 'transparent', whereas others may require extensive learning to be produced and interpreted. Nonverbal graphic representations are often combined with written language into complex multimodal expository texts. They convey some of the texts' meanings and interpreting them is an integral part of interpreting the whole text. Their prevalence in expository texts is increasing, and therefore learning about them is as important as learning about written texts (Kress \& van Leeuwen, 2006).

\section{Nonverbal representations and expository texts in early childhood education}

Young children are accustomed to taking and viewing pictures, identifying logos of wellknown companies and icons in electronic devices, observing adults when they use software maps for navigation. When properly used, nonverbal graphic representations can enable children to overcome the gap between their relatively high linguistic and cognitive abilities and their lack of proficiency in written language. The most notable example is illustrated books, but other nonverbal representations such as icons and calendars are also very helpful tools (Teubal \& Guberman, 2014).

In preschools, expository texts are included in the broad category of non-fiction. Nonfiction books on a variety of subjects, such as plants, wildlife or machines, may provide children with bases for later studies, since they enrich children's world knowledge and vocabulary, and acquaint them with expository text genres. Such exposure is especially important for children who have limited access to literacy at home (Duke \& Block, 2012; Murnane, Sawhill \& Snow, 2012). Unfortunately, preschoolers' have far less exposure to non-fiction than to narratives (Yopp \& Yopp, 2006). This phenomenon probably stems from the prevalent belief held by educators that children are uninterested in non-fiction 
texts, and are unable to understand them (Duke, Bennett-Armistead \& Roberts, 2003). However, when offered the choice, children are just as likely to choose non-fiction as narrative books. Some children may even prefer non-fiction to other texts (Correia, 2011). Research on preschoolers' production of non-fiction texts focuses mainly on drawing as a means of presenting their conceptualizations (Bakar, 2017; Gallenstein, 2005) and recording their observations during scientific activities (Brooks, 2003; Preston, 2016). Studies on observation records found that drawing focuses children's attention (Brooks, 2003), improves their memory of the recorded objects (Fox \& Lee, 2013) and may serve as a basis for further learning (Brooks, 2003; Guberman \& Teubal, 2014). Nonetheless, to produce scientific illustrations, children need specific instructions and examples (Brooks, 2003; Preston, 2016). Even junior high school pupils struggle to find a balance between generalization and abstraction on the one hand, and precision on the other hand, and they often omit significant details or include irrelevant ones (Jewitt, Kress, Ogborn \& Tsatsarelis, 2001). The latter findings are consistent with the claim that scientific illustrations are culturally- shaped genres that require learning.

To conclude, preschool children need more extensive experience with expository texts, and nonverbal graphic representations may be useful resources to support such experience. However, research on preschool children's use of nonverbal graphic representations in expository texts production is very limited in comparison with research on narrative texts. The current study aims to help address this imbalance. It explores how preschool children use nonverbal graphic representations and expository text genre characteristics to produce texts that help them attain their goals. The study involves a definition, observation table, bird guide, information sheet, behavior instruction manual and bilingual dictionary. Each is a 'secondary genre', which has a typical content, form and structure, and is used by addressors in complex contexts such as science (Bakhtin, 1986). Specifically, the study questions are: When do children need expository texts? What kinds of resources do they choose to convey meanings? How do these resources and their combinations contribute to the meaning of each particular text?

\section{Method}

The current study is a practice oriented research, which strives to produce "knowledge that can be implemented by practitioners in solving practical problems" (Bleijenbergh, Korzilius \& Verschuren, 2011, p. 148). A multiple case study methodology (Flyvbjerg, 2011) was used that claims that each case, unique as it may be, can be a valuable resource for knowledge and insights.

\section{Participants}

The participants are four Israeli preschool teachers and their students: one preschool for 3-4 year olds, one for 3-5 year olds and two kindergartens for 4-6 year olds. One preschool and one kindergarten are located in low-class neighborhoods and the other two in middle class neighborhoods. One kindergarten is in the center of Israel and the others are in the north. 


\section{Data collection}

This study was conducted following on from an in-service teacher education program aimed at enhancing literacy in preschools. Participating teachers learned about activities that can enhance literacy and world knowledge in preschools and about the potential contribution of nonverbal representations. They were encouraged to introduce relevant texts to their classes' activities. For example, when the children were looking after fish, the preschool library had fiction as well as non-fiction books dealing with fish, and access to web pages about aquarium maintenance and fish care instructions. Teachers were instructed to be attentive to the children's questions and goals, and to suggest reading and producing texts together with the children, to support children's activities. The teachers documented text production events and shared them with their colleagues. Documentation included a written description of the context that led to text production, transcripts of children's conversations relating to text production, and photographs of the texts, taken with the teachers' cell phones.. They added comments explaining the meaning of representations that were unclear to outsiders. After the end of the program, the teacher educator who administered the program asked for their consent to analyze the documentations they had provided and they all agreed.

\section{Data Analysis}

Data analysis is based on: (1) Teachers' documentations and comments about the context in which each of the texts was produced. This analysis answers the first question about situations in which the need for expository texts arises and helps to establish the goals the texts attempt to achieve.

(2) The texts themselves. Texts are analyzed in terms of 'what is there' (cf. Jewitt et al., 2001; Kenner, 1999). This involves looking at genre characteristics that are apparent in the productions and comparing them with the literature about each genre. Verbal and nonverbal representations and text layout's analyses rely on Kress and van Leeuwen (2006). Donald's (1991) text functions: mind extension, mind sharing and mind regulation are referred to during content analyses.

\section{Results}

The results are presented in four sections, one per case: (1) constructing a definition of an unfamiliar word, (2) preparing an observation table to collect data, (3) forming a bird guide, and (4) producing an information sheet, an instruction manual and a bi-lingual dictionary to support fish care. Each section begins with a description of the production context, and then the texts are presented and analyzed.

\section{Definition}

Production context: The definition below was produced in a kindergarten. The teacher was talking with the children about the history of Israel and that the first settlers suffered from 
malaria (kadaxat in Hebrew). The children learned about the symptoms of malaria and that it is transmitted by Anopheles mosquito bites. These mosquitoes lived in the swamps the settlers were draining. The teacher and the children decided to prepare an entry for their kindergarten's dictionary in order to remember that word. This is an example of mind extension (Donald, 1991) since the text expands users' capacity to retrieve information. The kindergarten's library had a dictionary which they used when they encountered unfamiliar words. Its entries served as a model for the definition genre. The teacher kept the definitions the children produced in transparent plastic covers and bound them into a dictionary that was available to the children throughout the year.

Definition analysis: Figure 1 is a definition of the word 'malaria'. The page is divided into two parts. The term kadaxat is written at the top of the page. This is the only use of writing in this text. Beneath the term is a large frame with illustrations. Frames indicate that the enclosed elements are connected (Kress \& van Leeuwen, 2006). The illustrations within the frame are also divided into two main components, separated by a large blank space (Kress \& van Leeuwen, 2006). At the bottom of the page, a patient is lying on a stretcher carried by two people. That image indicates that malaria is a serious disease, and that patients need help. It is possible that the cultural practice of evacuating seriously ill (or injured) patients on a stretcher (to an ambulance and then to a hospital) inspired the child to choose this image. At the top of the frame is a drawing of a mosquito. Its large size (in proportion to the people) and central position indicate that it has an important role (Kress \& van Leeuwen, 2006). A common form for a definition is: [the defined term] is a [taxonomic information: superordinate or subordinate category] that [short description of distinguishing characteristics] (Benelli, Belacchi, Gini \& Lucangeli, 2006). Page layout weaves the definition's three elements into a coherent text: Malaria (the defined term) is a (equivalence portrayed by the frame) serious disease (superordinate category) in which mosquitos have an important role (distinguishing characteristic).

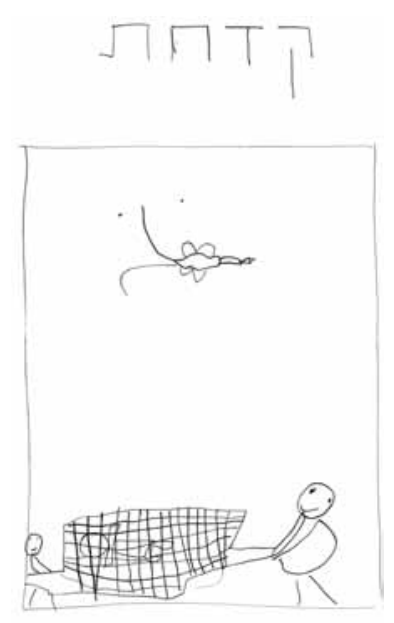

Figure 1. Malaria

definition 


\section{Observation table}

Production context: The preschool children planted radish seeds and followed their development. One day, the children spotted a few uprooted plants in their garden and observed the leaves and the roots. One child asked whether the roots were longer than the leaves, and the teacher suggested measuring both their lengths. The children recorded the measurements to the best of their ability. Figure 2 shows four nonverbal graphic representations of the measured lengths.

Although reading the measurements is possible from some of the representations, the children found it was tedious, and that it was very difficult to compare the measurements. The teacher suggested using a table. While they were preparing the table, the children learned how to make a table and to read the data.

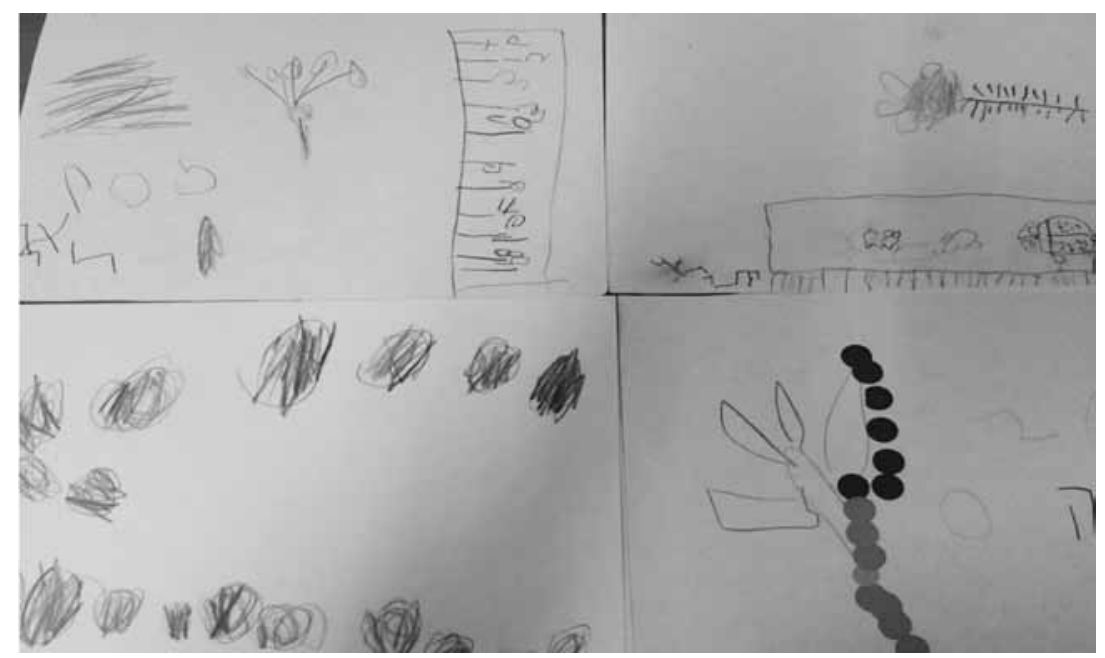

Figure 2. Different representations of length.

On the top right is an illustration of the plant -root and leaves next to a ruler. On the top left is a similar illustration, yet digits are visible next to the scales on the ruler. On the bottom right, colorful stickers indicate root length and the length of one of the leaves. Each sticker represents one centimeter. On the bottom left, green circles represent the length of the leaf above ground, and brown circles represent the length of the root below ground. Each circle represents one centimeter. The plant is not depicted.

Observation table analysis: Figure 3 shows the table the teacher prepared with the children. The teacher wrote a title for the table, which presents the research question in bold blue letters. "What is longer in a radish?" The table has three columns, arranged according to the direction of writing in Hebrew from right to left. On the right-most column, the side 
aligned in Hebrew with known (Kress \& van Leeuwen, 2006), the teacher wrote the names of five children, each name in a separate row (From top to bottom: Uriel, Itay, Li-el, Talia and Efrat). On the top of the middle column, the teacher wrote, "Leaf length" and added a green icon depicting a leaf. On the top of the left- most column, the teacher wrote, "Root length" and added a brown icon depicting a root. The teacher also filled in the first row, recording the first child's measurements in the row that contains his name, Uriel $(5-6 \mathrm{~cm}$ for the leaf and $11 \mathrm{~cm}$ for the root). Then, the children recorded their own measurements, each child in his or her row. The table was built according to the prevailing convention, where each column and row has something in common, and comparisons are made between adjacent areas (Tversky, 2001). The table clearly shows a small variability in root length $(10-11 \mathrm{~cm}$.$) , and that in most of the plants, the roots were longer than the leaves.$ The teacher summarized the findings and wrote the conclusion: "The roots!..." in bold blue letters on the table's bottom line, on the left side. The bottom of the page is aligned with the real, and the left-most side presents 'new' information (Kress \& van Leeuwen, 2006). By scanning the table from top to bottom and from right to left, viewers can grasp the entire process at a glance: research question, evidence and conclusion. All of the texts the children produced exemplify the mind extension and mind sharing functions of texts (Donald, 1991). Nonetheless, in comparison to their previous attempts to represent their measurements, the children experienced how easy it was to record, retain, retrieve, process and share data when supported by a table (Wainer, 1992).

The conversation that took place the next day shows that the children either remembered or read the measurements they recorded, and that they understood the relationship between their question, records and conclusion.

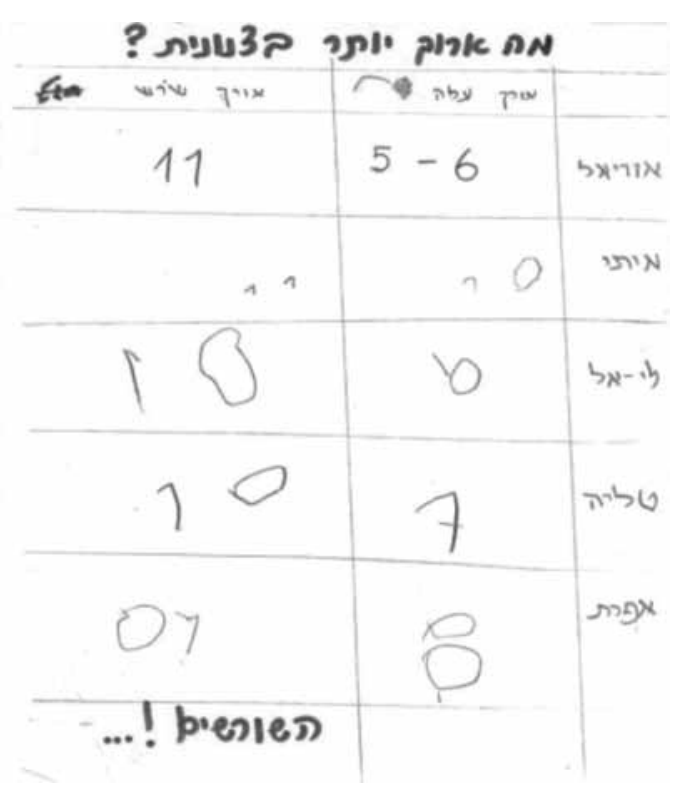

Figure 3. A table, recording root (left) and leaf length measurements. 
Teacher: Yesterday we filled in the table with the measurements we took. Who wants to remind us why we wrote the lengths of the leaves and the roots?

Uriel: Because I wanted to see which was longer.

Itay: I have a $10 \mathrm{~cm}$ [leaf] length and $11 \mathrm{~cm}$ root length. The root is longer by one number.

Teacher: Yes, one centimeter longer....

Teacher: Uriel initially thought the root was longer than the leaves. Was he right?

Li-el: Yes!

\section{Bird guide}

Production context: The kindergarten children who produced the bird guide in Figure 4 discovered a nest with two eggs in the kindergarten's yard. They wanted to find out the species of bird that built it. They waited and watched for several days but the bird did not return. They decided to take pictures of the birds that frequented the yard and compare them with those listed in the kindergarten's bird guide. They discovered that there were six species of birds. They carefully examined the pictures of these species' nests and eggs in the kindergarten's bird guide, and the teacher read the verbal descriptions of their nesting habits. Based on the number and color of the eggs, as well as the location of the nest (beneath the roof) they reached the conclusion that the abandoned nest belonged to a dove. Thus, the text they read helped them solve a 'mystery' they were engaged with. Following the discovery, they decided to create a bird guide of their own, and summarize the knowledge they acquired. This bird guide was prepared for their own use (as the one in the library had too many 'irrelevant' entries) and for sharing with family members and visitors. Conserving the knowledge they gathered is an example of mind extension, whereas sharing it with others is an example of mind sharing (Donald, 1991). Figure 4 shows the dove's entry in the children's bird guide.

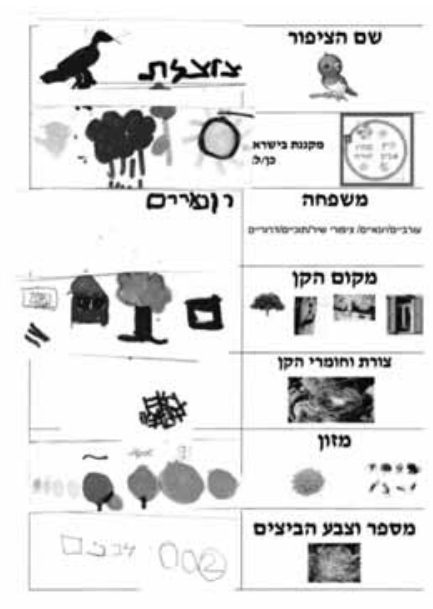

Figure 4. Entry for the dove in the kindergarten produced bird guide. 
Bird guide analysis: The teacher prepared the table format (Figure 4): two columns and seven rows. On the right column, aligned with 'known information' (Kress \& van Leeuwen, 2006) she printed headers of descriptive categories. These were from top to bottom: 1. Name of the bird and a bird image. 2. A circle with names of the four seasons and an icon to represent each one inscribed in a square frame, and the words 'nests in Israel yes / no'. 3. Bird-family, with four options beneath. 4 . Nest location, with images of four options beneath. 5 . Nest's shape and materials, with a photograph of a nest beneath. 6 . Food, with small images of seeds beneath. 7. Number and color of eggs, with a photograph of a nest with blue colored eggs beneath.

The children filled in the information about the birds. Figure 4 shows the dove's entry from that bird guide. 1. The children wrote the lower-frequency technical term 'dove' (Tzotzelet) as the bird's name, instead of the common, but scientifically unconventional term, 'pigeon'. Next to the name, they added a black silhouette of a dove. Silhouettes are a common feature in bird guides. They allow users to identify birds' categories when viewing conditions are too poor for identifying species. 2. Four drawings represent the nesting seasons (from left to right: cloud for fall, rain for winter, flower for spring and sun for summer). These are very typical of Israel's climate. 3 . The children wrote the dove's family name, Columbidae (Yoniyim). 4. and 5. Children used realistic drawings to represent nest locations and shape. 6. Colorful icons represent the dove's food, which they had not actually observed. 7 . The children drew two eggs on the bottom row, encircled the numeral ' 2 ', and wrote the word 'white' (levanim) ${ }^{3}$ to indicate the eggs' color. The written word attests to children's awareness of their readers' expectations. Normally, readers interpret the white color of a page as 'blank'. Had the children left the eggs 'uncolored', readers would have assumed that information about color was not provided. Throughout the text, children chose the most suitable signs to convey meanings: writing for names, drawing for shapes and a numeral for quantity (Dockrell \& Teubal, 2007). Creating the guide was an excellent opportunity for the children to organize their knowledge into the abstract categories the teacher (and the library's bird guide) provided. The guide also afforded exposure to the fact that expository texts use technical terms, such as the taxonomic meaning of the word 'family' that is different from the one the children were familiar with.

\section{Texts supporting fish care: information sheet, instruction manual and bilingual dictionary}

Production context: The teacher brought a fish tank to the preschool, and the children were fascinated by the fish. While observing, they asked many questions: "When do they go to sleep and where is their bed?"; "Where are its holes?" (nostrils); "What do they eat?" As these questions indicate, the children were unfamiliar with the aquatic world. They used gestures and context- dependent words (such as "it") as substitutes for content words they did not know.

To answer these questions (and many more), the teacher asked the children to talk to their parents, and to share the information with their peers. The death of three fish enabled the children to observe them closely with a magnifying glass and learn about their anatomy. 
Additional information was gathered from books and the internet. Finally, they decided to prepare the following texts: an information sheet on fish (Figure 5) to record the information they gathered; a fish care instruction manual (Figure 6) to protect the fish from unintended harm; and a bilingual Hebrew-Russian dictionary with fish-related terms and icons (figure 7) to allow for communication about the fish between family members, preschool staff and children.

Information sheet analysis: Figure 5 shows the information sheet. The teacher prepared the overall format, from top to bottom: 1. a title in bold letters 'Identity Card', borrowing a feature from another textual genre (Coutinho \& Miranda, 2009). 2. "Name: "Fish". 3. "Body structure". 4. "Food". 5. A header "Aquarium of" and the preschool's name in the center and an illustration of an aquarium beneath, next to a schematic tree. Overall, the structure of the information sheet was similar to an encyclopedia entry: name, anatomy, food and habitat.

The children added schematic drawings of fish. Next to 'body structure', they drew arrows pointing at significant body parts of the schematic fish and wrote their names. From top to bottom: scales (kaskasim), eye (ayin), side (tzad) and fin (snapir). An additional arrow points at the tail. These may help children remember the vocabulary they acquired. The children attached photographs of food items they gave to the fish and wrote their names. From right to left: meat (basar), bread (lexem) and matzah ${ }^{4}$. These foods are specific not only to the culture but also to this preschool. The information sheet was used to help children recall the information as well as the terms they learned, thus fulfilling the mind extension function (Donald, 1991).

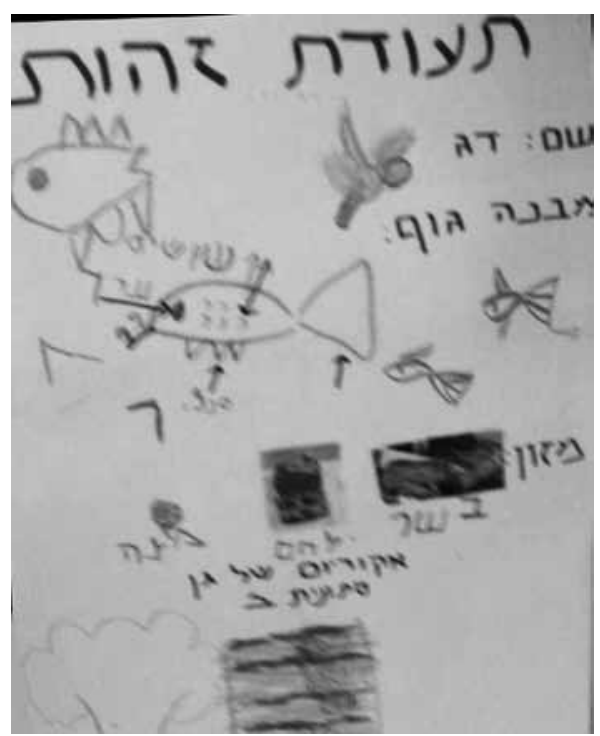

Figure 5. Information sheet about fish. 
Instruction manual analysis: Figure 6 shows the fish care instruction manual. They must be fed every day (top right); it is forbidden to leave them without water (top left); to take them out of the water (bottom right) or to step on them (bottom left). The teacher wrote and the children represented the instructions with schematic drawings and the icon X to denote a prohibition. The teacher's written language and the children's sign complexes convey the same meanings. The teacher chose to write, whereas the children appropriated the conventions of behavior regulating signs. This manual exemplifies the mind regulation function (Donald, 1991) as it helps children monitor their own behavior, refrain from harmful behavior and maintain the fish care routine.

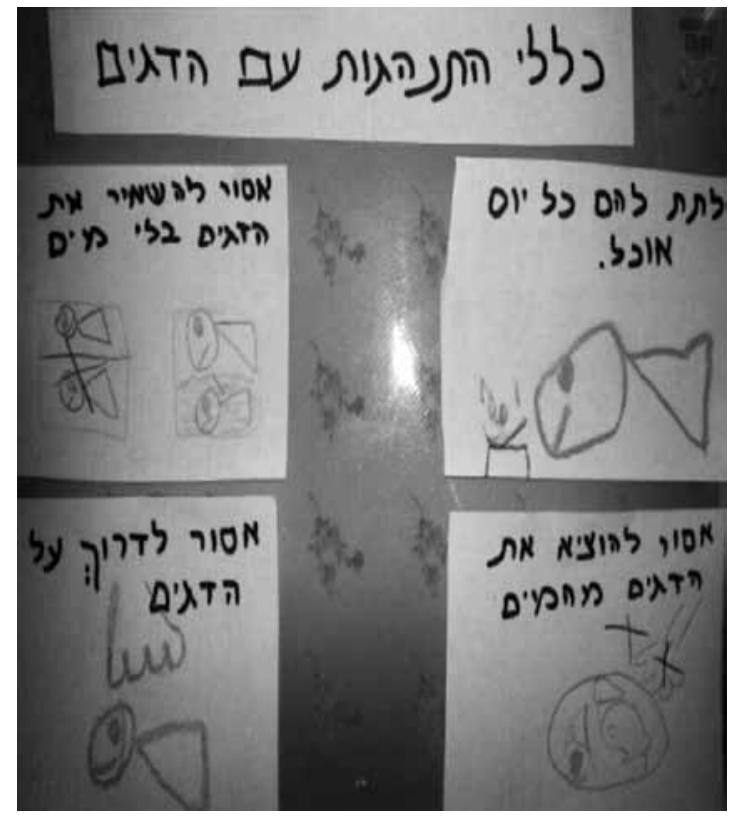

Figure 6. Fish care instruction manual.

Bi-lingual dictionary analysis: Figure 7 shows the Hebrew-Russian dictionary with fishrelated terms. The dictionary is structured as a table with three columns: The Hebrew terms on the right, the Russian - in the central column, and the left column is for drawings produced by the children, explaining each of the terms (from top to bottom: fish, water, fish tank, fin and gills). Interestingly, when dealing with specific body parts, the children used black color to emphasize the relevant parts, and omitted them from other drawings, thus facilitating interpretation (Kress \& van Leeuwen, 2006). The dictionary helped its users overcome linguistic barriers. During conversations, participants could point to the relevant representations and thus clarify what they meant. This is an example of the mind sharing function of texts (Donald, 1991). 


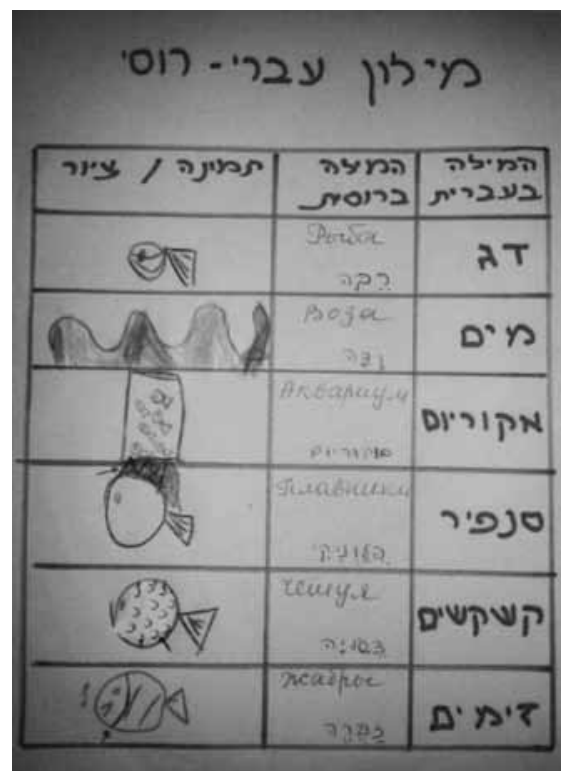

Figure 7. Hebrew-

Russian dictionary with fish-related terms.

\section{Summary and conclusions}

The current paper shows that expository texts of diverse genres may be useful for children in contexts that attract their engagement, serve their goals and support their learning (Bezemer \& Kress, 2016). Teachers' mediation helped children "read", appropriate and produce the expository texts they needed. The texts that children produced bear genre characteristics of the texts they reviewed to solve their questions. For example, dictionary definitions to disambiguate an unfamiliar word or an encyclopedia entry for information about fish (Coutinho \& Miranda, 2009; Heidmann \& Adam, 2007). While "reading" and producing expository texts, children were exposed to diverse knowledge domains. They encountered unfamiliar vocabulary, including technical terms, related to these domains (Duke \& Block, 2012; Murnane et al., 2012; Snow, 2017), as well as abstract conceptualizations aligned with the paradigmatic mode of thinking (Bruner, 1986; Schleppegrell, 2001; Snow \& Uccelli, 2009), such as "body structure", "family" and "season". Such encounters may help children address the challenges involved in literacy, and especially those associated with expository texts.

The children used diverse types of representations in the texts they produced: written words, numerals, icons, tables and drawings. Some of these seem 'transparent' whereas others require learning pertaining to production as well as conventions of use. For example, children's participation in table production was 'peripheral' (Wenger \& Lave, 1991). They merely recorded their observations following their teacher's preparation of the table format and demonstration how to record observations in a table. Nonetheless, they were 
later able to read their records from the table. Drawing a silhouette did not require specific tuition, yet silhouettes are a genre specific characteristic of bird guides that children learned through exposure and use (Heidmann \& Adam, 2007). These experiences may have enriched their meaning making resources.

All of the representations the children read and produced were 'graphic', i.e., they involved relatively permanent marks on a two-dimensional space. These allowed children to record and review the information they gathered (on malaria, radish roots and leaves, birds and fish), re-read their texts and draw conclusions from the kindergarten's library bird guide as well as from their own observation table. These are all examples of the mind extension function of texts, since they expand producers' ability to store and retrieve information. Children used the behavior instruction manual to monitor their own behavior, maintain the fish care routine and refrain from harmful actions. This is an example of the mind regulation function of texts. In addition, all of the texts were accessible to children, staff and family members, allowing conversers to exchange information, ideas and feelings even when the relevant vocabulary was unavailable. This is an example of the mind sharing function of texts (Clark, 1997; Donald, 1991; Olson, 1994).

Children were aware of the range of meaning conveying resources they had, choosing the most apt resources, considering their affordances as well as the effort required for production while designing their texts (Kress, 2015; Kress \& Jewitt, 2003): written words for naming, drawing for shapes, and numerals for quantity and length. Furthermore, they were aware of their 'addressors' role, and took various measures to facilitate their texts' interpretation (Kress, 2015; Kress \& Jewitt, 2003; Rijlaarsdam et al., 2008). In some instances, they used both words and nonverbal representations to convey their meanings, in other instances they used arrows or color to emphasize significant details, and eliminated details they thought were irrelevant or misleading (Kress \& van Leeuwen, 2006). The resultant texts were cohesive, de-contextualized multimodal units of communication (Donaldson, 1978; Kress, 2015; Kress \& Jewitt, 2003; Sweet \& Snow, 2003). Repeated use of expository texts may enrich children's text producing resources (Hammer et al., 2005) and help them gradually become full members in text producing communities (Wenger \& Lave, 1991).

The study limitations are its small scale, and short duration. In the future, it is recommended to conduct longitudinal studies that will follow young children's developing abilities to read and produce expository texts.

\section{Notes}

1. Bezemer and Kress (2016, p. 15) challenge language centrality, embracing a "fully fledged multimodal approach" according to which "all modes are potentially of equal semiotic standing". They name approaches that keep language in the center of their analyses and view other modes as merely embellishing language "multimodality lite". I'm caught somewhere in the middle: Although I agree with Bezemer and Kress, nonverbal graphic representations, as well as written language, are central in education and in the academic world, and children need to appropriate them.

2. Donald refers to graphic devices rather than graphic representations. 
3. 'levanim', is the plural macular form of 'white' ('lavan'). In this context, the form is not conventional because in Hebrew the noun 'egg' is feminine.

4. A matzah is an unleavened bread in the form of a large cracker, eaten during the Passover festival.

\section{References}

Bakar, K. (2017) Young Children's Representations of Addition in Problem Solving. Creative Education, 8(14), 2232-2242.

Bakhtin, M. M. (1986). The problem of speech genres. In: C. Emerson \& M. Holquist (Eds.), Speech genres and other late essays (V. McGee, Trans., pp. 60-102). Austin: University of Texas Press.

Barthes, R. (1981). Camera lucida: Reflections on photography. New York: Hill and Wang.

Bazerman, C. (2009). Genre and cognitive development: beyond writing to learn. In: C. Bazerman, C. Bonini, \& D. Figueiredo (Eds). Genre in a changing world (Ch. 14, pp. 279294). Fort Collins, Colorado: The WAC Clearinghouse.

Bazerman, C. (2013). Understanding the lifelong journey of writing development. Infancia y Aprendizaje, 36 (4), 421-441.

Benelli, B., Belacchi, C., Gini, G., \& Lucangeli D. (2006). 'To define means to say what you know about things': the development of definitional skills as metalinguistic acquisition. Journal of Child Language, 33(1), 71-97.

Berman, R. A., \& Nir, B. (2009). Cognitive and linguistic factors in evaluating text quality: global versus local? In: V. Evans \& S. Pourcel (eds). New directions in cognitive linguistics (pp. 421-440). Amsterdam: John Benjamins.

Bezemer, J. \& Kress, G. (2016). Multimodality, learning and communication. London: Routledge.

Bleijenbergh, I., Korzilius, H., \& Verschuren, P. (2011). Methodological criteria for the internal validity and utility of practice oriented research. Quality \& Quantity 45(1), 145-156.

Brooks, M. (2003). Drawing to learn. NAEYC Beyond Journal. http://www.naeyc.org/files/ yc/file/200309/DrawingtoLearn.pdf

Bruner, J. S. (1986). Actual minds, possible worlds. Cambridge, Mass.: Harvard University Press.

Clark, A. (1997). Being there: Putting brain, body and world together again. Cambridge, MA: MIT Press.

Clark, H. H., \& Fox Tree, J. E. (2002). Using uh and um in spontaneous speaking. Cognition, 84, 73-111.

Correia, M. P. (2011). Fiction vs. informational texts: Which will kindergartners choose? YC Young Children; 66(6), 100-104.

Coutinho, M. A., \& Miranda, F. (2009). To describe genres: problems and strategies. In: C. Bazerman, A. Bonini \& D. Figueiredo (Eds.), Genre in a changing world (Ch. 3, pp. 3556). Fort Collins, Colorado: The WAC Clearinghouse.

Dockrell, J., \& Teubal, E. (2007). Distinguishing numeracy from literacy: evidence from children's early notations. In: E. Teubal, J. Dockrell, L. Tolchinsky, \& J. E. Dockrell (Eds.), 
Notational knowledge: developmental and historical perspectives (pp. 113-158). Sense: Rotterdam.

Donald, M. (1991). Origins of the modern mind: Three stages in the evolution of culture and cognition. Cambridge, MA: Harvard University Press.

Donaldson, M. (1978). Children's minds. Glasgow, UK: Fontana / Collins.

Duke N. K., Bennett-Armistead S., \& Roberts E. M. (2003). Filling the great void: Why we should bring nonfiction into the early-grade classroom. American Educator. Retrieved from: http://www.aft.org/periodical/american-educator/spring-2003/filling-great-void.

Duke, N.K. \& Block, M.K. (2012). Improving reading in the primary grades. The Future of Children, 22(2), 55-72.

Flyvbjerg, B. (2011). Case study. In: N. K. Denzin and Y. S. Lincoln (Eds.). The Sage Handbook of Qualitative Research, (4th ed., pp. 301-316). Thousand Oaks, CA: Sage.

Fox, J. \& Lee, J. (2013). When children draw vs when children don't: exploring the effects of observational drawing in science. Creative Education, 4, 11-14.

Gallenstein, N. L. (2005). Never too young for a concept map. Science and Children, 43(1), 44-47.

Guberman, A., \& Teubal, E. (2014). The potential contribution of graphic texts to the education of preschool children in multi-cultural settings. In: P. M. Rabensteiner \& G. R. Rabensteiner (Eds.) Internationalization in teacher education (Vol. 7: Near-East, pp. 60-72). Hohengehren, Germany: Schneider.

Hammer, D., Elby, A, Scherr, R., \& Redish, E. (2005). Resources, framing, and transfer. In: J. Mestre (Ed.), Transfer of learning: Research and perspectives (Ch. 3, pp. 89-119). Greenwich, Connecticut: Information Age Publishing.

Halliday, M. A. K. and Hasan, R. (1976). Cohesion in English. London: Longman.

Halliday, M. A. K \& Martin, J. R (1993). Writing science: literacy and discursive power. Pittsburgh, University of Pittsburgh Press.

Heidmann, U., \& Adam, J. M. (2007). Text linguistics and comparative literature: towards an interdisciplinary approach to written tales. Angela Carter's translations of Perrault. In: D. R. Miller \& M. Turci (Eds.), Language and verbal art revisited: linguistic approaches to the study of literature (Ch. 7, pp. 181- 196). London: Equinox Publishing Ltd.

Hoff, E. (2006). How social contexts support and shape language development. Developmental Review, 26, 55-88.

Jewitt, C., Kress, G., Ogborn, J., \& Tsatsarelis, C. (2001). Exploring learning through visual, actional and linguistic communication: the multimodal environment of a science classroom. Educational Review, 53(1), 5-18.

Kenner, C. (1999). Children's understandings of text in a multilingual nursery. Language and Education, 13(1), 1-16.

Kress, G. (2015). Semiotic work: applied linguistics and a social semiotic account of multimodality. AILA Review, 28, 49-71.

Kress, G., \& Jewitt, C. (2003). Introduction. In: G. Kress \& C. Jewitt (Eds.), Multimodal literacy (Ch. 1, pp. 1-18). NY: Peter Lang.

Kress, G., \& Selander, S. (2012). Multimodal design, learning and cultures of recognition. Internet and Higher Education, 15, 265-268. 
Kress, G. \& van Leeuwen, T. (2006). Reading images: The grammar of visual design (second edition). NY: Routledge.

Lave, J., \& Wenger, E. (1991). Situated learning: Legitimate peripheral participation. Cambridge: Cambridge University Press.

Livnat, Z. (2012). Dialogue, science and academic writing. Amsterdam: John Benjamins.

Mitchelmore, M. (1998). Young students' concepts of turning and angle. Cognition and Instruction, 16(3), 265-284.

Murnane, R., Sawhill, I., \& Snow, C. (2012). Literacy challenges for the twenty-first century: Introducing the issue. The Future of Children, 22(2), 3-15.

Olson, D. (1994). The world on paper: The conceptual and cognitive implications of writing and reading. New York: Cambridge University Press.

Preston, C. (2016). Try this: Draw like a scientist. Teaching Science, 62, 4-8.

Rijlaarsdam, G., Braaksma, M., Couzijn, M., Janssen, T., Raedts, M., Van Steendam, E., Toorenaar, A., \& Van den Bergh, H. (2008). Observation of peers in learning to write, Practice and Research. Journal of Writing Research, 1(1), 53-83.

Scarborough, H. (2001). Connecting early language and literacy to later reading (dis)abilities: evidence, theory and practice. In: S. B. Neuman \& D. K. Dickinson (Eds). Handbook of early literacy research (pp. 97-110). NY: Guilford.

Schleppegrell, M. J. (2001). Linguistic features of the language of schooling. Linguistics and Education, 12(4), 431-459.

Snow, C.E. (2017). The role of vocabulary versus knowledge in children's language learning: a fifty-year perspective. Infancia y Aprendizaje, 40(1), 1-18.

Snow, C.E., Burns, M. S., \& Griffin, P. (1998). Preventing reading difficulties in young children. Washington, DC: National Academy Press.

Snow, C.E., \& Uccelli, P. (2009). The challenge of academic language. In: D. R. Olson \& N. Torrance (eds). The Cambridge Handbook of Literacy (pp. 112-133). Cambridge: Cambridge University Press.

Sweet, A. P., \& Snow, C. E. (Eds). (2003). Rethinking reading comprehension. Guilford Publications. New York: Guilford.

Teubal, E., \& Guberman, A. (2014). Graphic texts: Literacy enhancing tools in early childhood. Rotterdam, The Netherlands: Sense.

Tversky, B. (1999). What does drawing reveal about thinking? In: J.S. Gero \& B. Tversky (Eds.), Visual and spatial reasoning in design (93-101). Sydney, Australia: Key Centre of Design Computing and Cognition.

Tversky, B. (2001). Spatial schemas in depictions. In: M. Gattis, M. (ed).. Spatial schemas and abstract thought (Ch. 4, pp. 79-112). Cambridge, Mass.: MIT Press.

UNESCO Institute for Statistics (2003). Literacy skills for the world of tomorrow: Further results from PISA 2000. Paris: OECD

UNESCO EFA Global Monitoring Report Team (2005). Why literacy matters. In: Education for All Global Monitoring Report 2006 (ch. 5, pp. 135-145). Paris: UNESCO.

Wainer, H. (1992). Understanding graphs and tables. Educational Researcher, 21(1), 14-23.

Yopp, R.H., \& Yopp, H.K. (2006). Informational text as read-alouds at school and home. Journal of Literacy Research, 38, 37-51. 
Resumen: Los textos expositivos representan la realidad de acuerdo a una modalidad lógico-científica. Frecuentemente consisten en lenguaje escrito y representaciones gráficas no verbales, tales como tablas y gráficos, cada uno de los cuales transmite algunos de los significados del texto (Kress \& van Leeuwen, 2006). Los textos expositivos son predominantes en el mundo académico y el sistema educativo, y resultan desafiantes en todos los niveles educativos (Berman \& Nir, 2009).

El presente estudio explora la producción de textos expositivos por parte de niños en nivel inicial: cuándo necesitan este tipo de textos, qué recursos eligen, y cómo estos recursos contribuyen al significado textual.

Método: Los participantes fueron cuatro docentes de nivel inicial en Israel y sus alumnos, de tres a seis años de edad. Cada docente documentó eventos de producción textual, incluyendo para ello la descripción de la producción textual, la transcripción de las conversaciones de los niños y fotografías de los textos con comentarios explicativos. El análisis textual se basó en la identificación de los marcadores de género (Coutinho \& Miranda, 2009), funciones del texto (Donald, 1991), las representaciones verbales y no verbales y la disposición del texto (Kress \& van Leeuwen, 2006).

Resultados: Los niños produjeron textos correspondientes a seis géneros: una definición, una tabla de observación, una guía de aves, una planilla informativa, un manual de instrucciones y un diccionario bilingüe. Estos textos les resultaron útiles para almacenar y recuperar información, monitorear su propio comportamiento y comunicarse con otras personas. Los niños utilizaron diversos tipos de representación: palabras escritas para nombrar, dibujos para formas, numerales para representar cantidad y longitud, tablas para organizar datos.

El estudio mostró que las representaciones gráficas no verbales enriquecen los recursos de producción textual de los niños, y pueden ayudarlos a aprehender y apropiarse gradualmente de los géneros textuales expositivos.

Palabras clave: Educación inicial - escritura expositiva - modalidades de aprendizaje aprendizaje activo.

Resumo: Os textos expositivos representam a realidade segundo uma modalidade lógico-científica. Eles geralmente consistem em linguagem escrita e representações gráficas não verbais, como tabelas e gráficos, cada um dos quais transmite alguns dos significados do texto (Kress \& van Leeuwen, 2006). Os textos expositivos são predominantes no mundo acadêmico e no sistema educacional, e são desafiadores em todos os níveis de ensino (Berman \& Nir, 2009).

Este estudo explora a produção de textos expositivos por crianças no nível inicial: quando precisam deste tipo de textos, que recursos escolhem e como esses recursos contribuem para o significado textual.

Método: Os participantes foram quatro professores de nível inicial em Israel e seus alunos, de três a seis anos de idade. Cada professor documentou eventos de produção textual, incluindo a descrição da produção textual, a transcrição das conversas das crianças e fotografias dos textos com comentários explicativos. A análise textual foi baseada na identi- 
ficação de marcadores de gênero (Coutinho \& Miranda, 2009), funções de texto (Donald, 1991), representações verbais e de layout não-verbal e texto (Kress \& van Leeuwen, 2006). Resultados: As crianças produziram textos correspondentes a seis gêneros: uma definição, uma tabela de observação, um guia de aves, uma ficha informativa, um manual de instruções e um dicionário bilíngüe. Esses textos foram úteis para armazenar e recuperar informações, monitorar seu próprio comportamento e se comunicar com outras pessoas. As crianças usaram diferentes tipos de representação: palavras escritas para nomear, desenhos para formas, numerais para representar quantidade e comprimento, tabelas para organizar os dados.

O estudo mostrou que as representações gráficas não verbais enriquecem os recursos de produção textual das crianças, podendo auxiliá-las a apreender e apropriar-se gradativamente dos gêneros textuais expositivos.

Palavras chave: Educação inicial - escrita expositiva - modalidades de aprendizagem aprendizagem ativa.

[Las traducciones de los abstracts fueron supervisadas por el autor de cada artículo] 